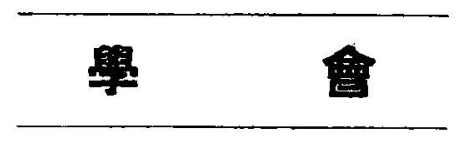

\title{
第5 回中國四國外科集談會演說抄䥻
}

（昭和 14 年6月 4 日 於岡山筴科大學第一講堂）

1. 手街用僌布代用としての新閒紙に

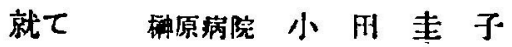

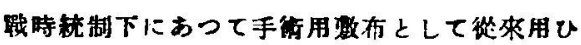
られてるる「ネル」不足のため新明科をつて代用 品とせんとす．其の察祭的效果を症例に就て速一 เท.

追加石山数授

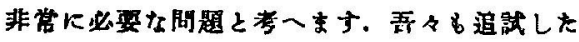
いと思ひます。

2. 空洞狀畸足の 1 例 石山外科 山 村 稔 青者は最近侵天性に他の足部㱦形を合併せナ゙猲

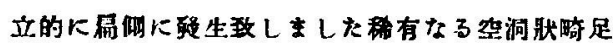

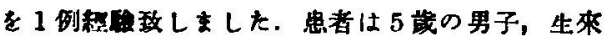

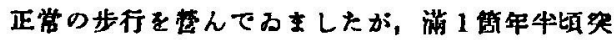

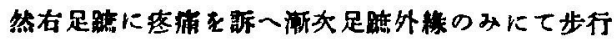
ナる栐になつたの゙学科を訪れました，会身所見

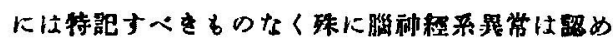

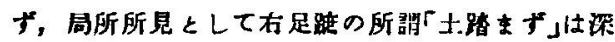

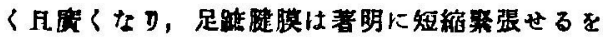

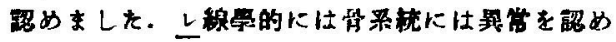

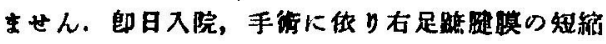

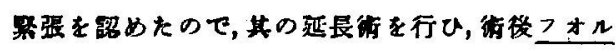

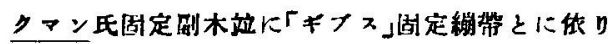

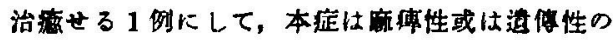

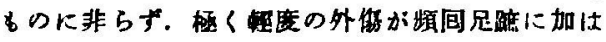

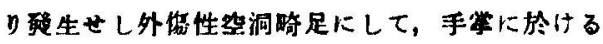

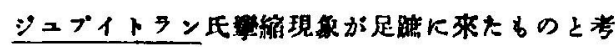
一๖.
3. 鎮骨 折簡易副木に就て

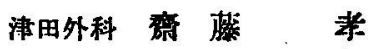

Dr. Amold 氏方 r Barrel atawe Splint」、と恰

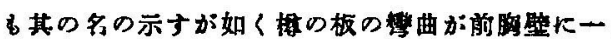
致せるを利用し頡骨る折に應用したり。此副机 改良を加い丈夫で固い蚂い木を用ひCまとして械 の木ここれを使用して比較的良轱果を得たるを以 て稆介せり。

4. 結侅性学䝢疼と愦診せられたる骨肉腫 (「レトテルザルコーム」) 津田外科 等: 力久男 患者は 17 瓷の女學生にして生來極好て健康に して票患を知らず，本年2月「パスケットボール」

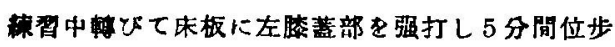
行不可能なりき，其の传間むなく左足に「ンヒレ」

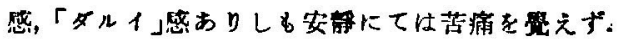

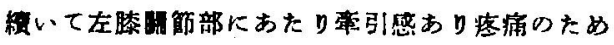
滕网飭は充分盾曲すること不可能となりたるた

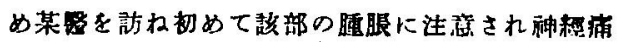

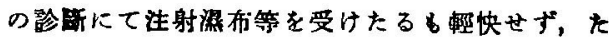

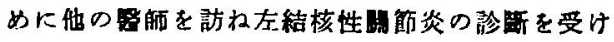

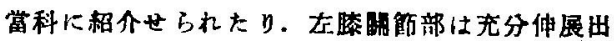
來ず，俓度の腫脹を見るる皮成は繁常なり．上渴

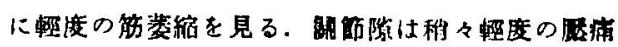

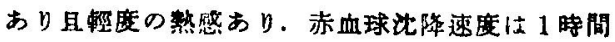
$55 ， 2$ 特間 94 にて稍々促道を示す。上線学政にて

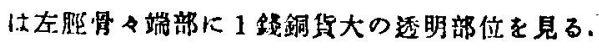

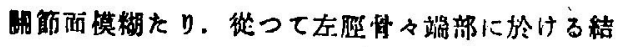

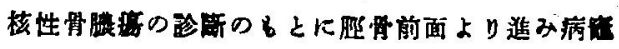




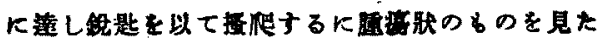

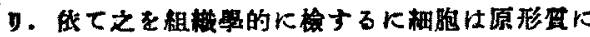

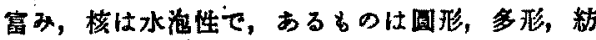

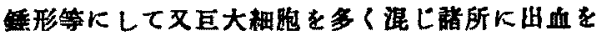

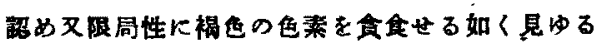

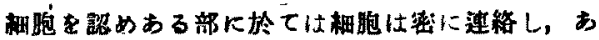

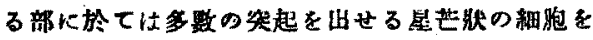

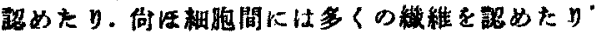
倲て以上の所見上り 1930 年 Roulet 氏务始めて提。

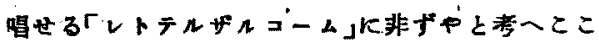
に報告せる次第なり。

5. 肺炎莯性滕關節炎 2 例

$$
\text { 三宅病院 西 们卓 察 }
$$

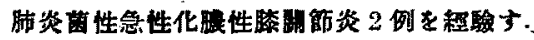

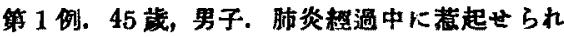

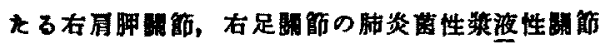

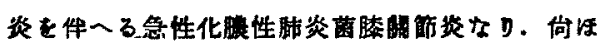

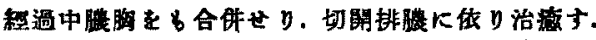

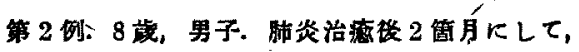

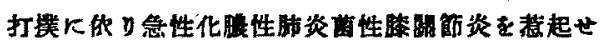

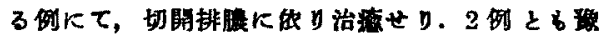

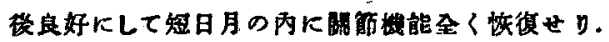

\section{道 加石山数授}

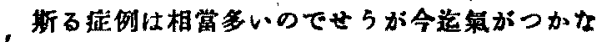
かつたるのかと思仕れる。かかる祭湅菌の澄明を

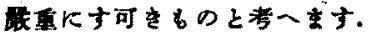

追加石山外科䈪尾秀一 第 1 例. 52 歳の女. 左侧念性肺炎第 12 病日上

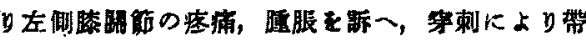

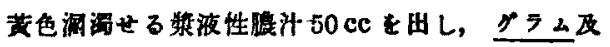

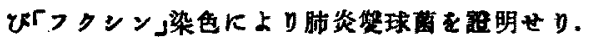

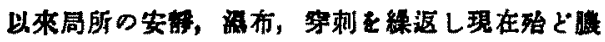

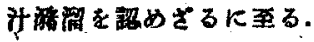

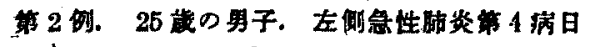

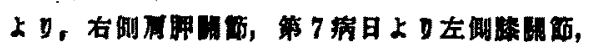

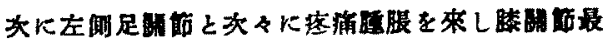

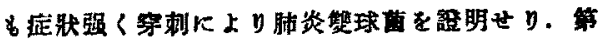

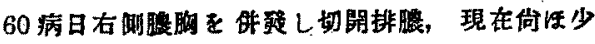

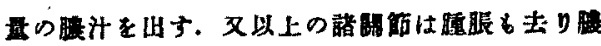

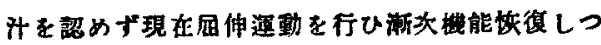
つむり.

6. 测維病性開第庭の 1 侧

$$
\text { 津田外科 留口, 毒 久 }
$$

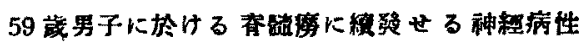

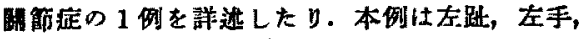

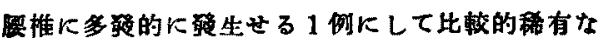

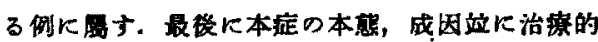
事項に關し間單に远でたり。

7. ホルネル氏拝候群を以て來れる乳兒 頸部肉腫 石山外科 松下 正

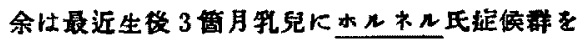

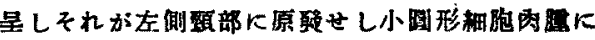

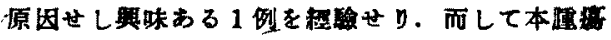

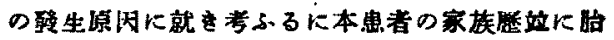

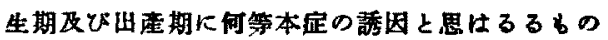

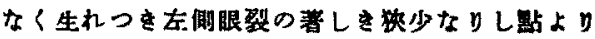
本腫塂が既に胎生期より存在せしるのなるてとは 明かにして恐らくは恹程性畦胞の迷芽より生ぜし

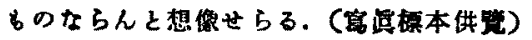

8. 初生兒に發生せる巨大大なる結滴糡混合 腫に就て 石山外科 三宅喜炏 郎 私は最近吾が石山外科於て扬生兒力巨大なる

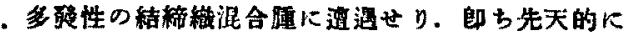

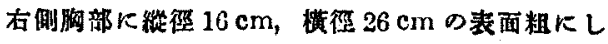

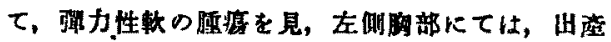

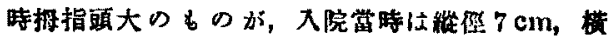

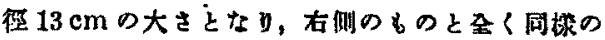

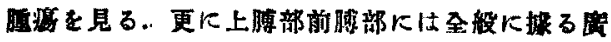

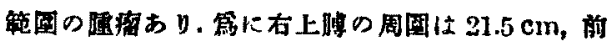

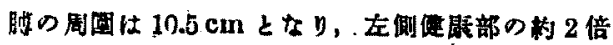




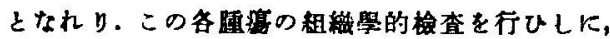

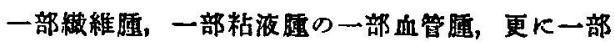

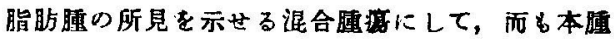

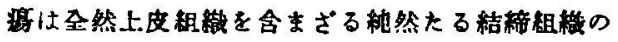
みよリなれるものにして，揓出硒本を見るた，多

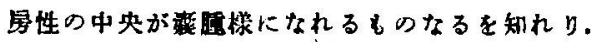

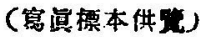

9. 劇烈なる坐骨神絓痛を來せる小骨盤 腔內の闻形細胞肉腫に就て

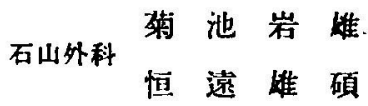

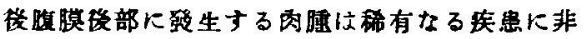

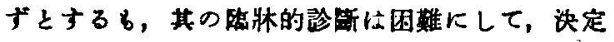

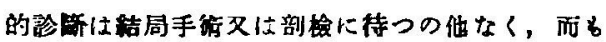

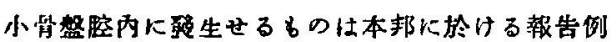

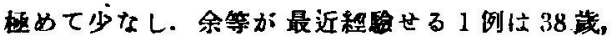
理髰業を管む男子にして, 昭和 13 年 8 月顷より 右大腿部の神程瘦訴一，14年 5 月排便，排尿隐 碍を挀一るに及どて吾教宔を訪れたるるのなり。

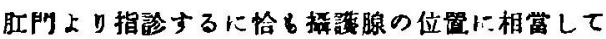

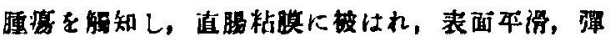

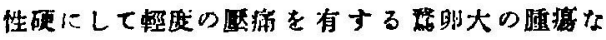

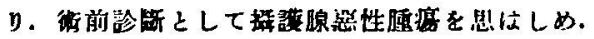

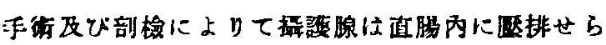

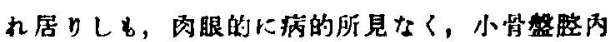

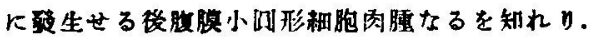

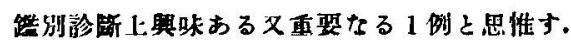

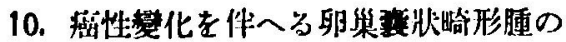
1 㘹例圆自 我部政法

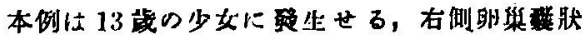

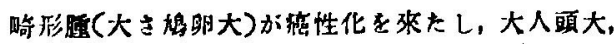

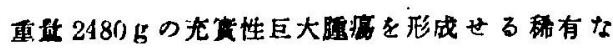

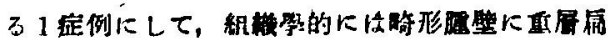

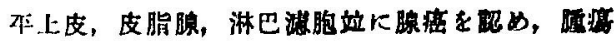

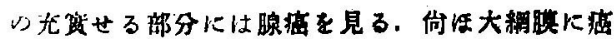

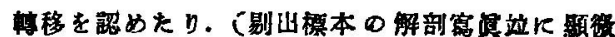

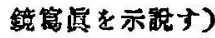

11.」 Leukoplakie を伴へる口唇癌の 1 例 津田外科滕原公平

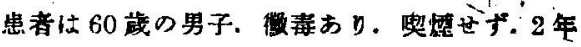
前に下口层粘膜に「ロイコブンキー」あり. 狗 5 管 月前より Ieukoplakieの前方に「ッモール」を生 ナ゙.5月8日に吾が外科を訪れる。下口屡全部を

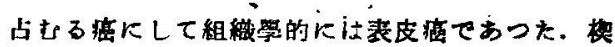

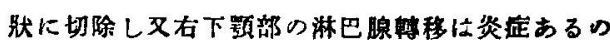

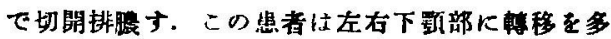
数有するので象㷋不良なり. Leukoplakie との睌 俰に就ては，楾々議論ちるる Leukoplakie の角

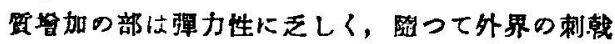
のために裂刢又は群裂を生ずれば深部のマルビギ

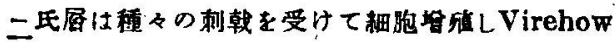
の刺戟境を以てすれば Leukoplakie より癌を發 生するをのと思考せるる。

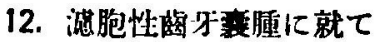

$$
\text { 石山外科 貆 时青爭 海 }
$$

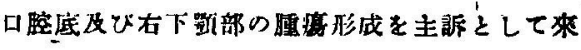

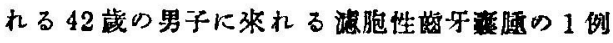
を報告し現今までの緦評的に現はれたる左右側

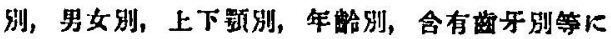
就て述ぶ。

$$
\text { 追加高松三宅德三郎 }
$$

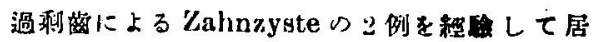

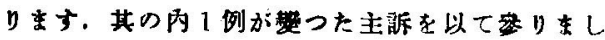
た面曰い例と思ひますので迫加します，患者は祭

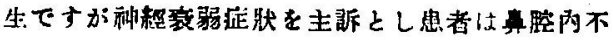

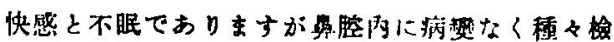
桦する。原因なりしるのがレントゲンにより切め $て$ Zahnzoyste $と よ る$ Nasenhöhle $の$ Reizなる ことを知り手術により全治した1例であります。 
13. 下肢く端紅痛症に對与る腰鶌部節狀 索切除術の效果に就て

倉㩆中央病院外科崖崎直治

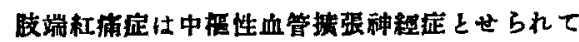

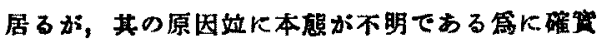

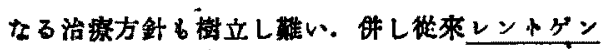

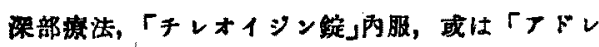
ナリン」「カルデノン」等の注射, 或は又神楆内 「フルコホル」注射が試みられてるる。吾々は最近

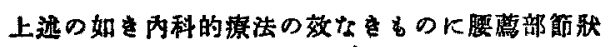

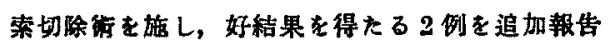
する. 第 1 例は 17 歲の中重生で, 譑因々認めら るるるのなくレて，兩下腿に治感を學える漛にな

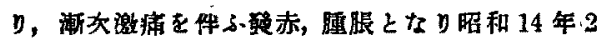
月 7 日吾々の外來を訪れた。 上述の如を为科的撩 法を試みたが全く效果を期待するととが出來なか

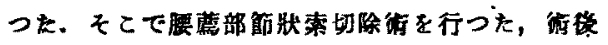

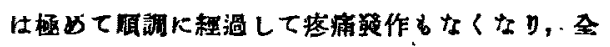

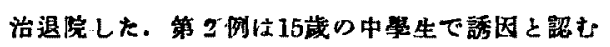
るものなくして雨下肢に激痛老件小破赤, 腫服を

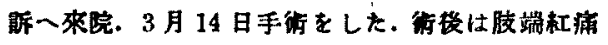
拝の作は繁くなったが Gangränを起して来た。 文矿によるとErythromelaegieが Akraaskhyxie に移行した例いあるが，本例は氷水で强く给した

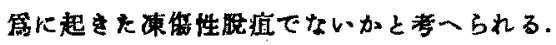

\section{遍 加石山数投}

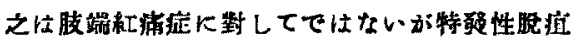

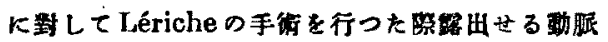

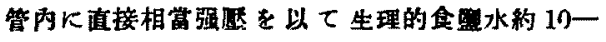

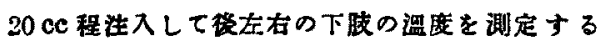

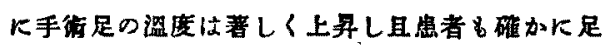
袋 1 枚程の溫暖さを感ナ゙るとふ而して其の持䍃

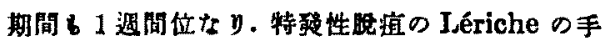

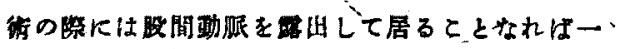

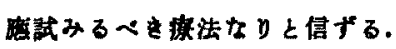

迡加山崎直 治

街後の效果は著明でありますが或程度の再䃑が

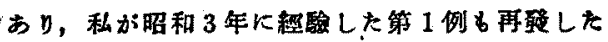

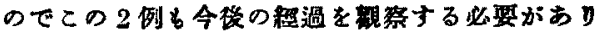

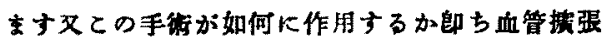

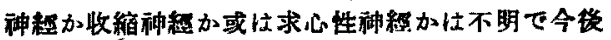
の研究を俟つ必要があり竜方。

14. 互斯蛙窝維炎 22 例

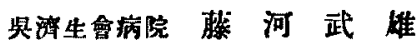

缺席

15. 男子孚瘦の 1 例 津田外科 䍑 本繁

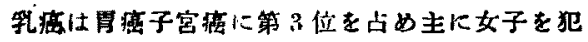

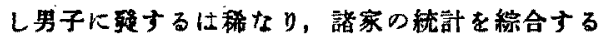
に大略全乳癌の $1 \%$ 外外を占山るるのにして其の 報告例教は泰西に於ては既に1000例を越ゆるる 本邦にて之が啹告例柱余の交缺より葫菓し得たる

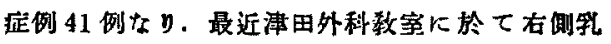

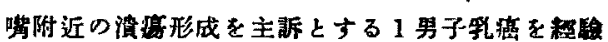
し更に之に 1 例を加んとするものなり。患者林某

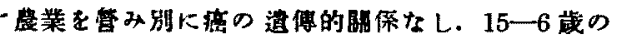

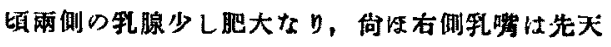

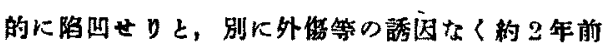

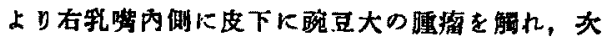

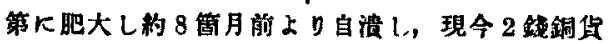

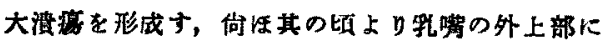

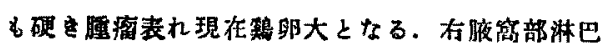
腺は 2-3 腫胀世 り赤血球汇降速度 1 時間 20，2

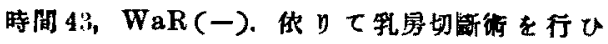
ハイデンハインの成形䔎を施し街を終る.37日に

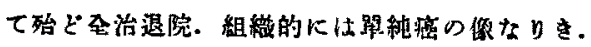

16. 乳㽽手術に於ける成形街に就て 津田外科 鈴 木 谌 輔

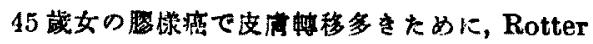

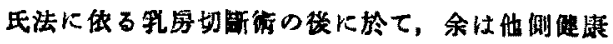




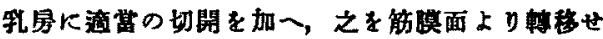

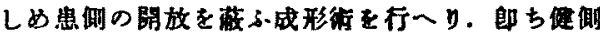

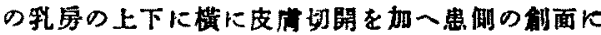

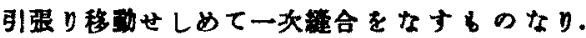
Sauerbruch，Payr の方法は践康侧孚房の㑡方に

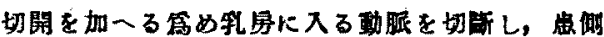

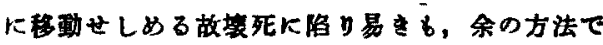
は移動せしめを乳是の烄死は起らない，何ほ Heidenhain 氏法による1例を運加せり。

筫問榊原亨

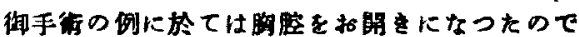
ナか。

答鉿 木甚輔

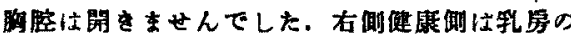
みに切閏を加へ，左方に移動させをした。

答㮵原㖟

ザゥェルフルフ氏等の柇原整形獄は元來乳庶の

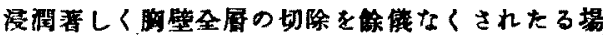

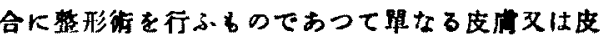

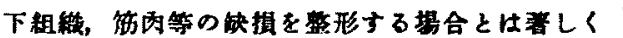

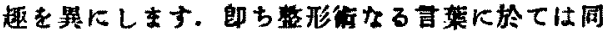

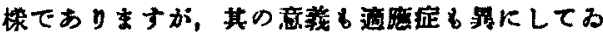

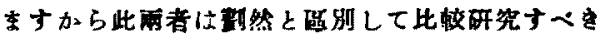

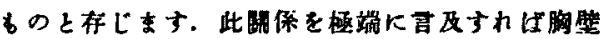

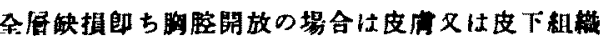

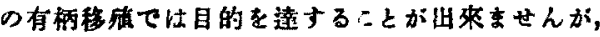

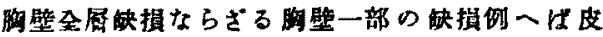

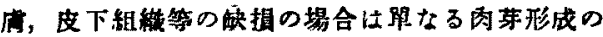

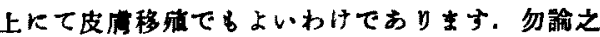

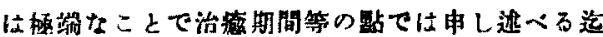
をないことであり寺す。

\section{7. 維隔案造影法}

\section{矿仙外科村良一}

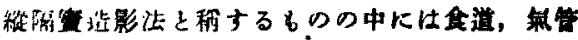

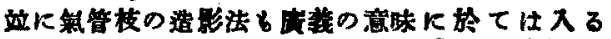

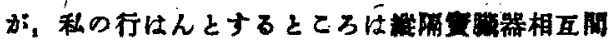
の開保を明がにせんとする造影法学味する。併

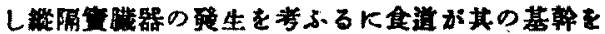
なナのであるから 1924 年 Iodoux 及ど Paquet

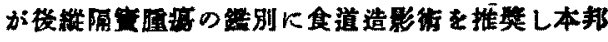

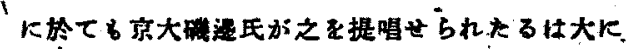

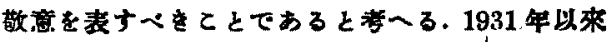

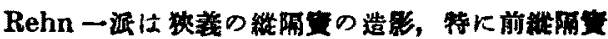

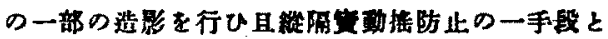

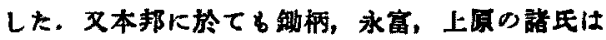

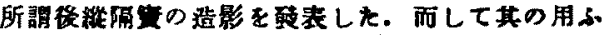
る所の造影佣は「ナフロヂール」トロトフスト」を 主としてるる。私る初めは「トロトラスト」用ひ

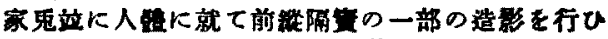

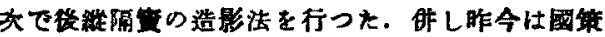

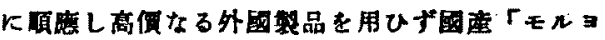

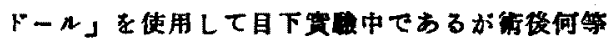

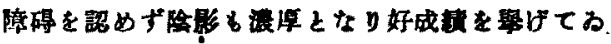

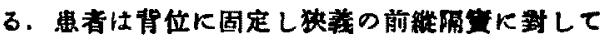

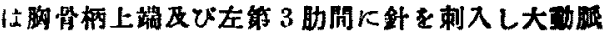

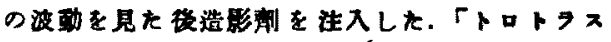
ト」12乃至 $20 \mathrm{cc} r モ y=F-n 」 100 \mathrm{c}$ 用Uて

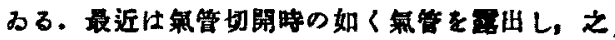

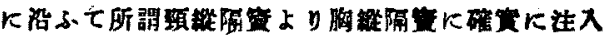
ちるカ法をとつておる．(2,3症例供算)

18. 肋水及已゙腹水注射站几紫外線照射 血輸血に就て 石山外科 杉山像之

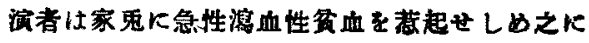

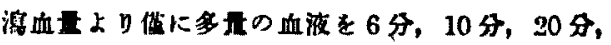

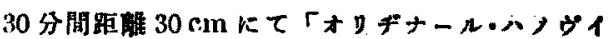

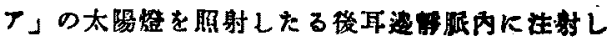

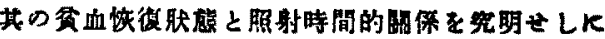

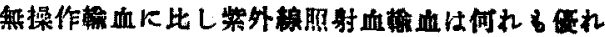

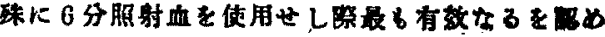




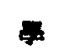

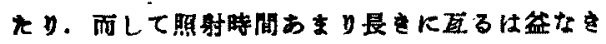

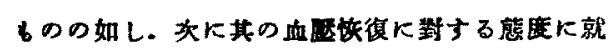
ては 6 分照射血を使用せし㬐 3 一時間にして正

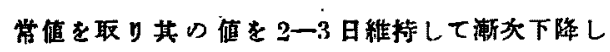
一定眼度に達したる镂は夫れを越えて降下する事 なし、之に反し一般榙血は 1-3時間にして正常

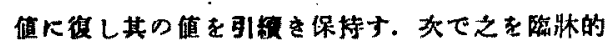

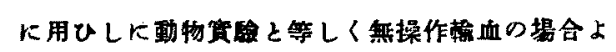

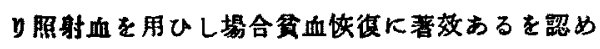
たる。其の盟射時䦐的には著しき差暴を認めず.

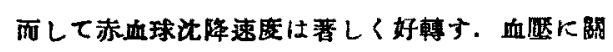

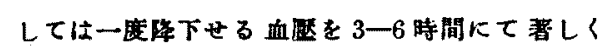
上年せしめ其の值を 3-4 日維持し渐次下降す。故

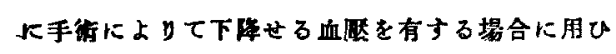

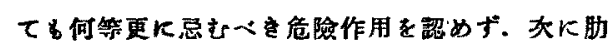

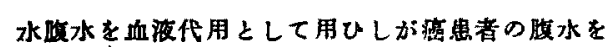
用ひたる境合は何れる家真を死しせしめたり。而 して此侮使用せし腹水江結核性腹脱炎「ネフロー

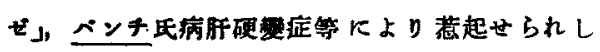
bのKして其の甭白会有量は $0.8 \%$ よ $40 \%$ K 至る。のを用ひしに腹水は助水より滕り且蛋白含

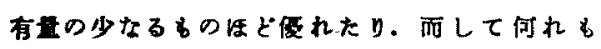

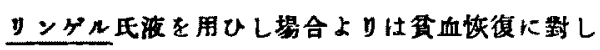

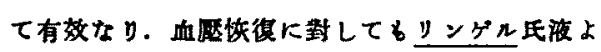

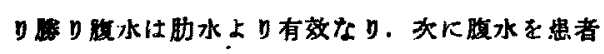

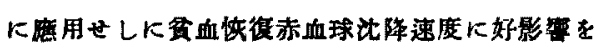
みとt.

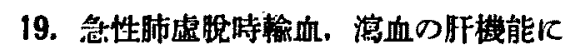
及的ナ影緐 石山外科石 F浩

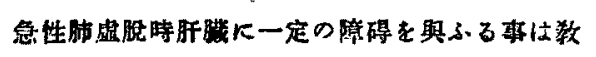

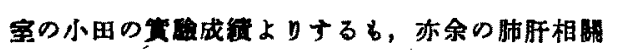

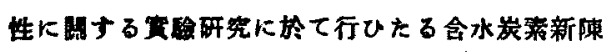

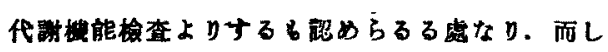

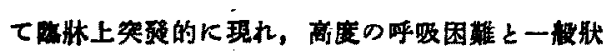

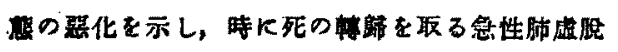

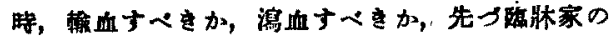

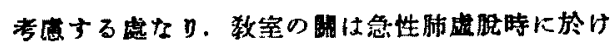

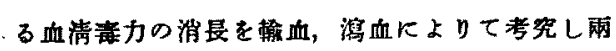

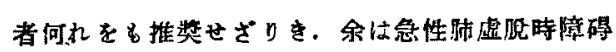

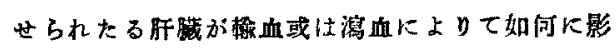
整さるるゃを象象に於て考究し，肝機能方面より

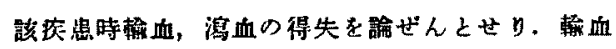

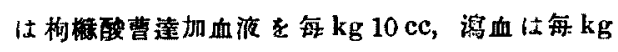

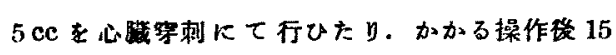
分にして1\%「ナソルビン」S淮液 $2 \mathrm{cc}$ 宛を注射

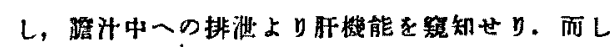
てての結果考急性肺虚脱時に於ける該色素排泄爿。

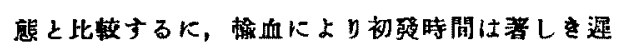

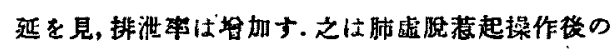

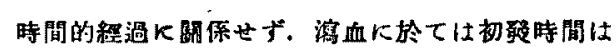

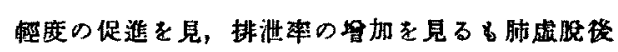

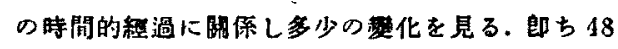

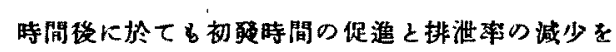

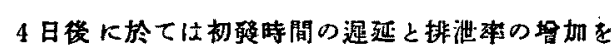

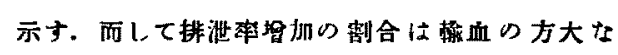
り. 源血に於て 2 例心死乚列を肺虚脱初期に於て 見たる事は注意すへき事項にして，かかる事項の みよりするを初期潟血は深甚の注意を型するるの

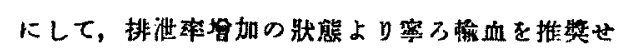

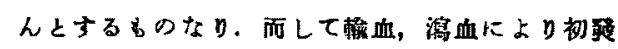

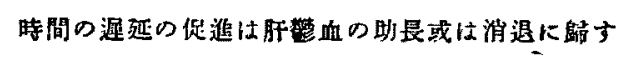
るを穻䓨と思惟す。

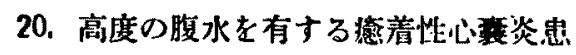

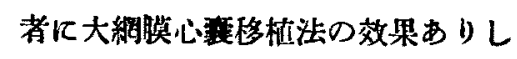

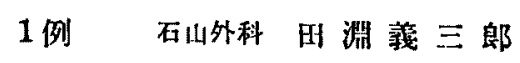

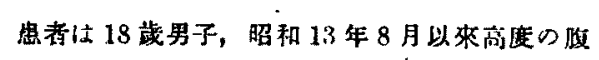

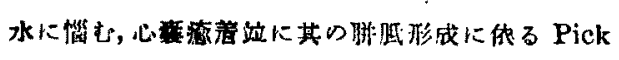
syndromに加ふるるに本熊在明かにし得ざりしす

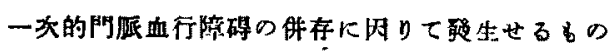

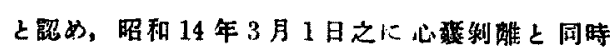

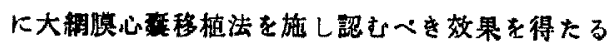


1 例に就て述与。

21. 蜔螼儿上る穿孔性㤂性腹膜炎 触山荒木病院 中村 俊 雄 缺唐

22. 肺炎雙球菌性腹膜炎の 1 例 津田外科 野 口義 久

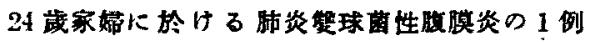
を報告したり，本例俚本症に比侪的特有士りとさ

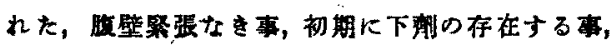

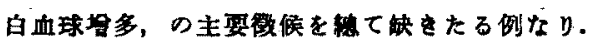
最後に自家例に於ける治㙩法に就き考按を加一た y.

\section{3. 踷新性腹暯炎に就て} 津田外科藤 山省 吾 余津田外科教豈に於て最近 15 简年間比遭造 せる男 2 名女 1 名計 3 名の䀧计性股朕炎に就て調 查せるに患者何れ650乃至60歲代にして丙2

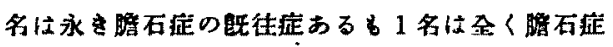

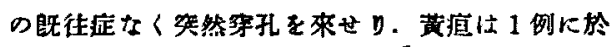

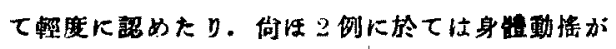

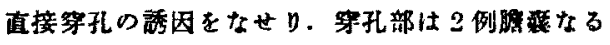

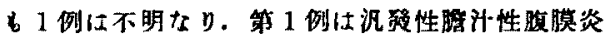

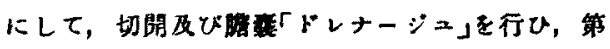

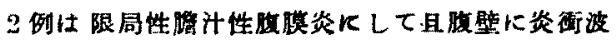

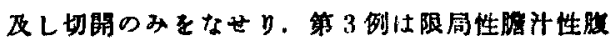

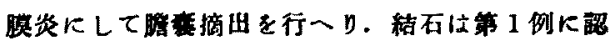
めたるのみなり．本症の稳防として賠石症に於て

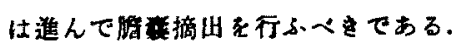

\section{4. 一ノツホ氏腹性紫琉病の 1 例 津田外科 原 正}

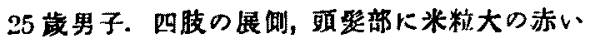

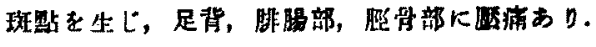

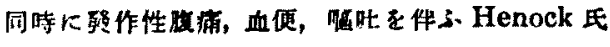

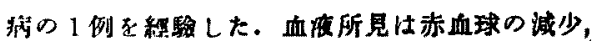

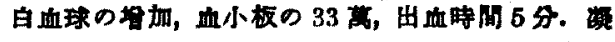
固時間 $\left(25^{\circ} \mathrm{C}\right) 10$ 分. 治療としてはVitamin C 就

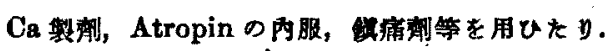

25. 傅研大腸菌瓦斯簀县菌混合血清使用 後に㖟生せる胃出血

\section{桶原病院 井口與志子}

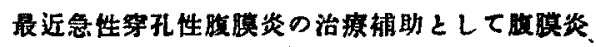

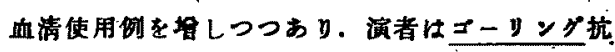

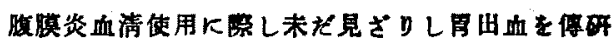

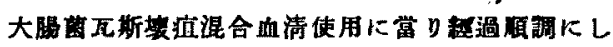

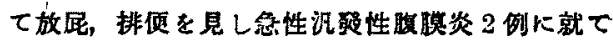

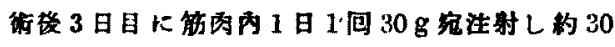

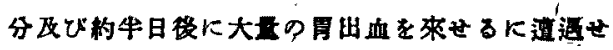

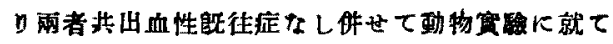
述へんとす。

\section{6. 持繶的十二指腸消息子括入法} 栖病院津 团次 郎

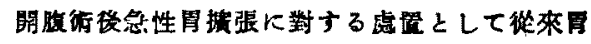

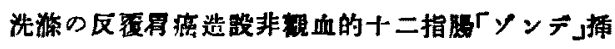

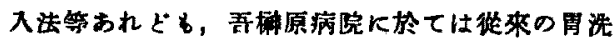

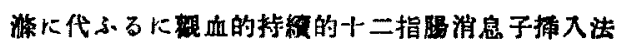

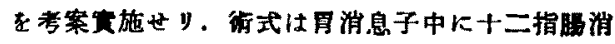

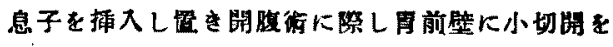
加一，次で口より十二指勝消息子を捕入せる原消 息を入れ，十二指渴消息子の「オリーフ」者壁に

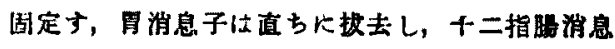
子のみ持悢的に描入し䈯基の口端は水中に入

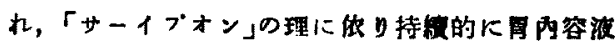

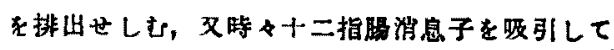
其の通通障碍老防を゙作せて目內の元斯を排出せし

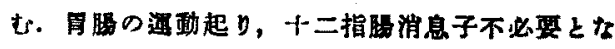

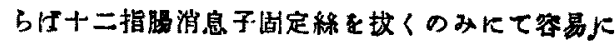

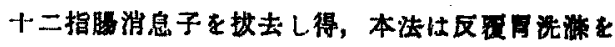

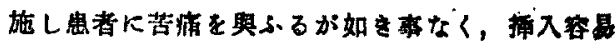

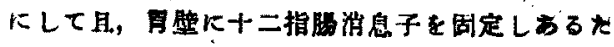




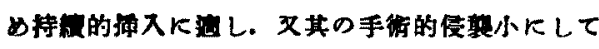

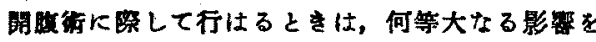
舆一ざる事等を特色とす，己を筫施せる症侧を舉 ヴここに啹㶵す.

\section{7. 街後精神障碍症例追加}

石山外科 和 $\mathrm{F}$ 進

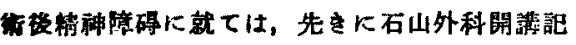

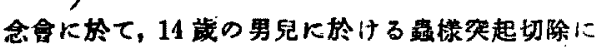

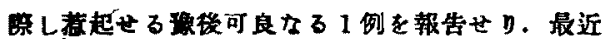

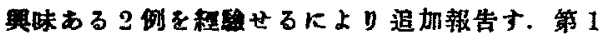

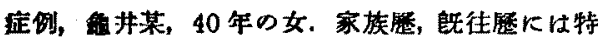

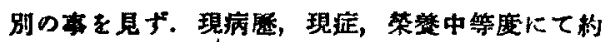
4 筒月前より李肪部に腫痛形成の主訴にて4月3

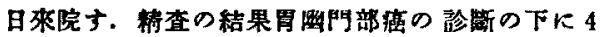

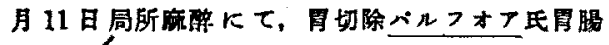

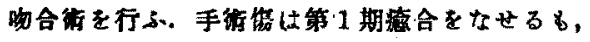

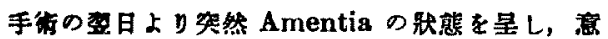

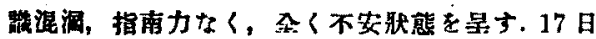

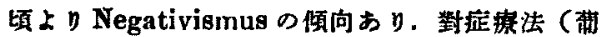

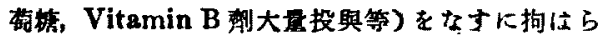

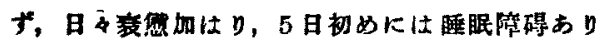

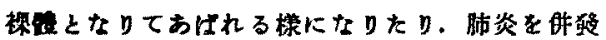

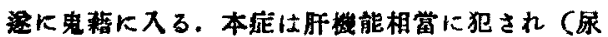
ミロン反應,「アソルビン」の反栕による) 新陳代

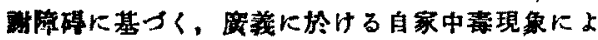
: る6の土らん，第 2 应例，中村某，66 年の女. 家

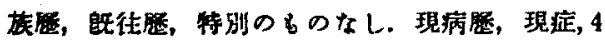

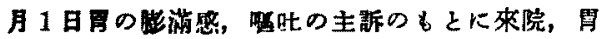

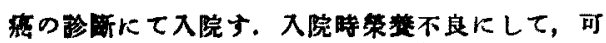
切の贯直あり，4月13日月切除，胃腸吻合街を

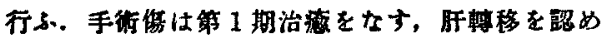

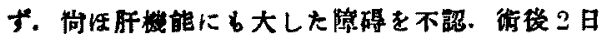

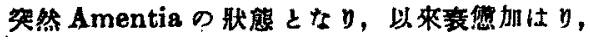

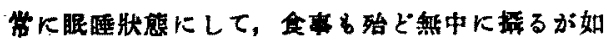

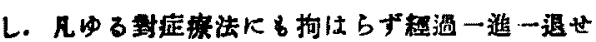

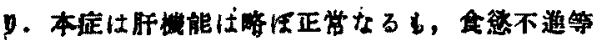

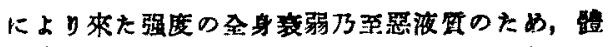
內に生じた中間新陳代謝物而による自家中毒によ るものならんと思惟せらる。

邉加神雨日赤渡遥傳二

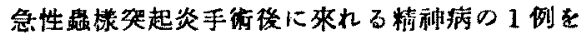

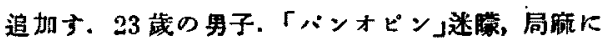

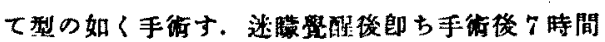

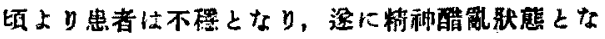

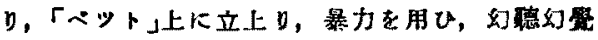

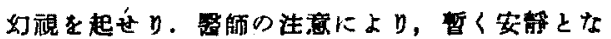

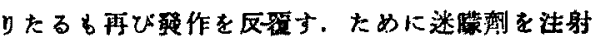

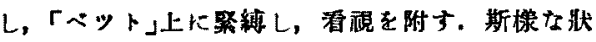

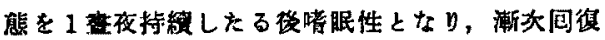

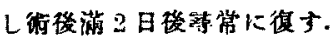

遍 加高松三宅德三郎

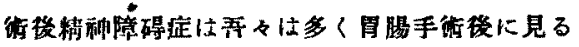

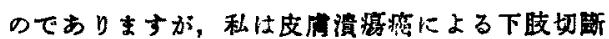

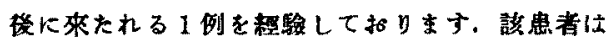

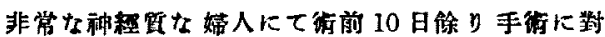
する恐㤢のため金事充分ともなかつた由であり

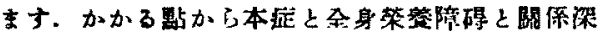
い栐に思ひ古すが御教示を願ひます。

追加不山教授 患者が饻荡してるる時，本庭は起り易いのであ りますが必ずしをてんな時ばかるとは限りませ

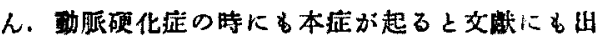
てるる。旰年 1 例入學試駗前の學尘に認めた若身 者方症例を和田君が報告しましたが，この症例は

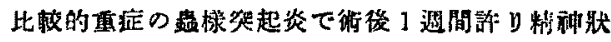

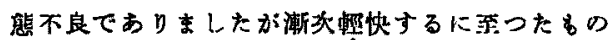
であります，ての患者江急性炎症でありますから

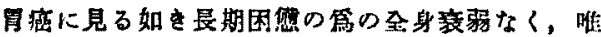

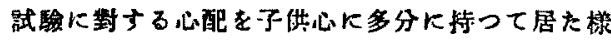
であります，故に管に肉祖的疲然のみが主因とる

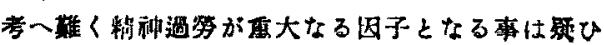
むを所と考一ます。 
28. 興味ある腸管皮下破裂に就て 高松三宅病院 和 田 新 一

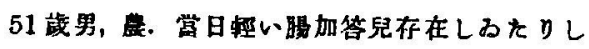

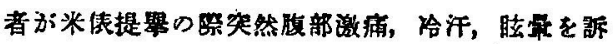

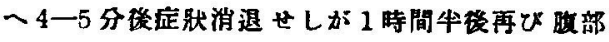

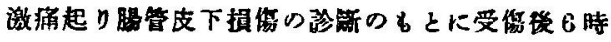
間目に手街を行ひ会治せるるのにして大なる外力

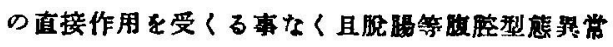

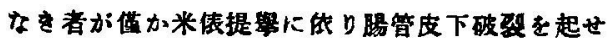
し1例Kして Motz の分類に依る nachd. Ber-

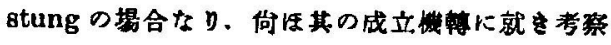
地等.

$$
\text { 追加憵松三宅德三郎 }
$$

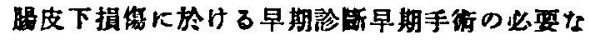
ることは今更申すまでもありませんが，其の原因

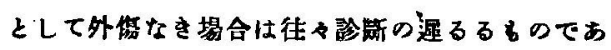

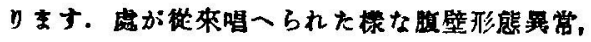

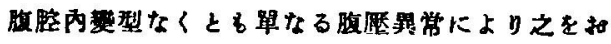
てす绵合おることに御注宽していただをたいので おります。

\section{9. 庙沉なる腸管重腫棬氣腫} 榞病院 井上秋 崔

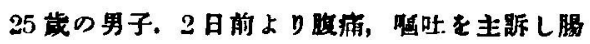

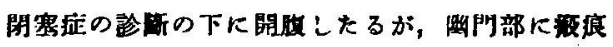

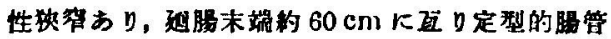

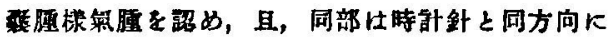

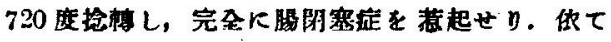

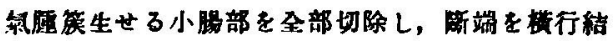

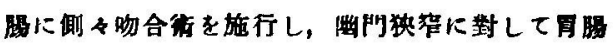

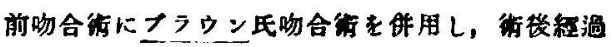
顸調 3 逝間にして全治退院せし 1 例を報告す。

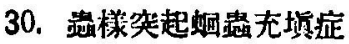

稀原病院 枯木蓬行

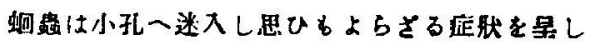

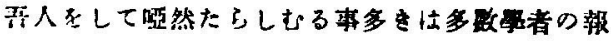

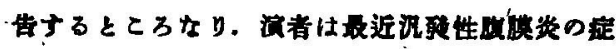

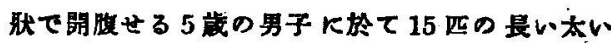

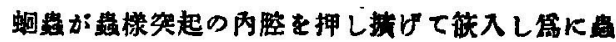
棌笑起は其の壁菲薄とたり長さ的 $15 \mathrm{~cm}$ ，根部の

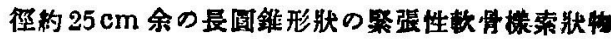

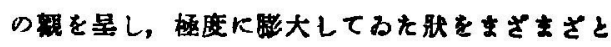
目整する阵侖を得たので1例ではあるが報告する 次第垊 可.

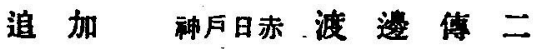

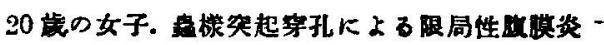

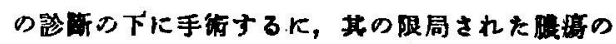

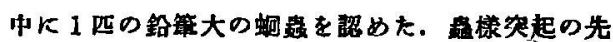

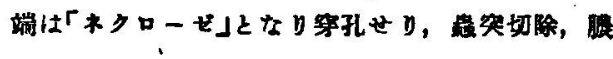

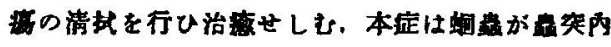

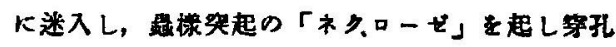

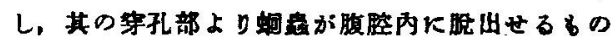
ty.

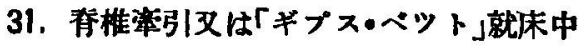

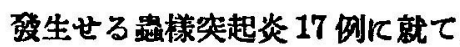
石山外科 的 村 一 魔

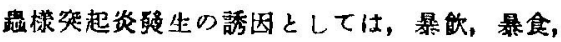

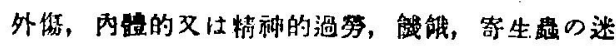

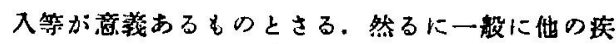

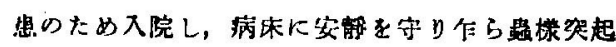

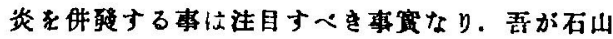
外科数室に於て，最近主として車椎「カリェス」 或は他の春椎疾患のため入院し，春推旁引又は

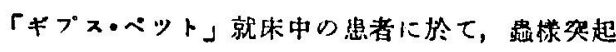

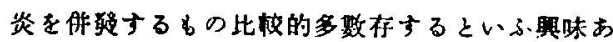

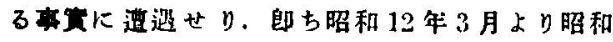

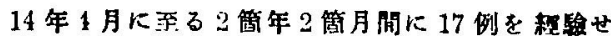
ク.之第 17 例中手微の行泣れたる13 例に就を，

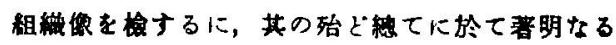

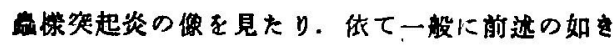

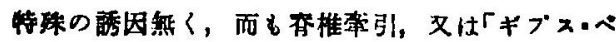




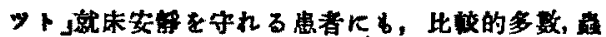

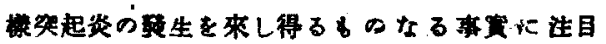

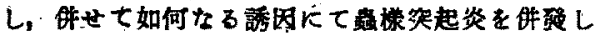

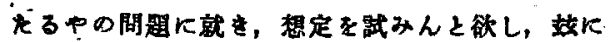

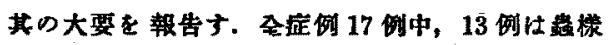

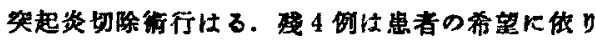

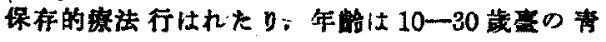

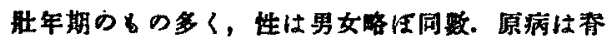

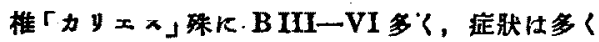

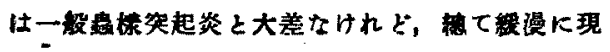
はる. 此ため吾々は数日相察の後手街行ひしる

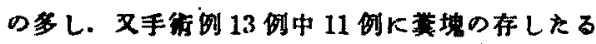
忙注目すいをなり，病理學的所見は，手街例 13 例

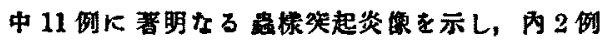

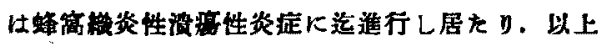

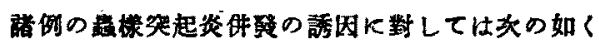

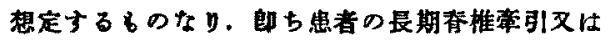

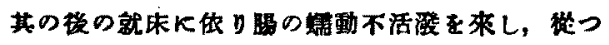

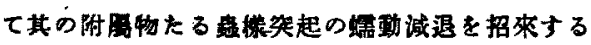

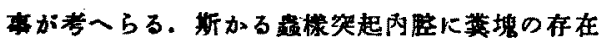
は所請開塞壁 (Cavite Close) を形成し，两容の

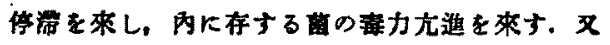

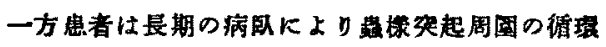

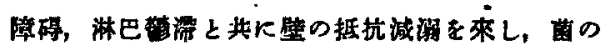
传入を客易ならしむる事考考一得るるのにて，以

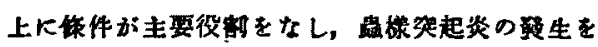

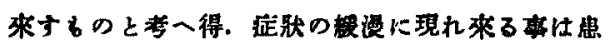

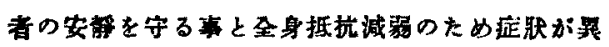
烈をとり現るるに非ずャ.

32. 維維垥殖性蟲様突起炎に就て 津田外科 中川美 雄”。

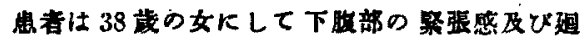
官部の原㾂を主挀とせるるのにして，物50日前

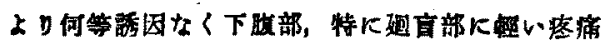

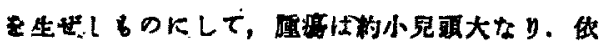

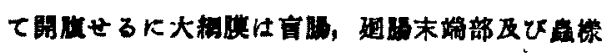

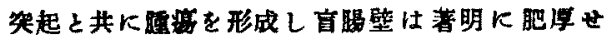

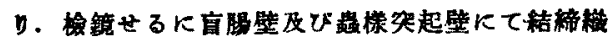
管殖を見をり。

追 加 石山外科上村良一

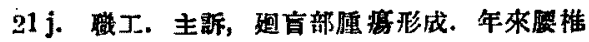

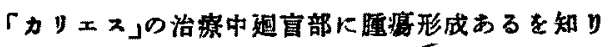

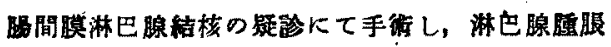

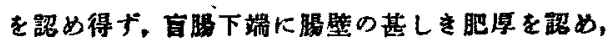

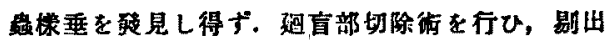

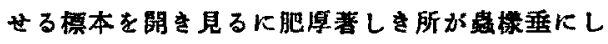
て其の壁の厚さ $1.5 \mathrm{~cm}$ ，中に小指頭大の烡石むり。

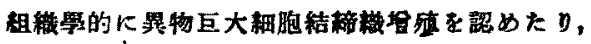

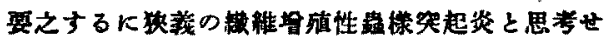
了1例なり.

33. 腸重棈症の原因となれる蛅様咨起 「ミキソグロプローザ」に就て 津田外科 横

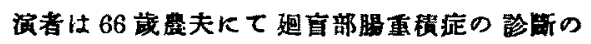

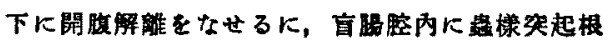

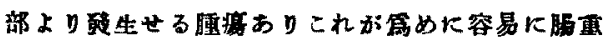

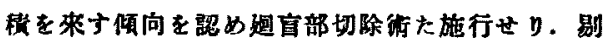

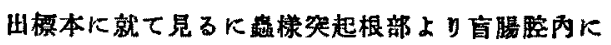

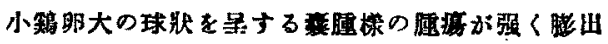

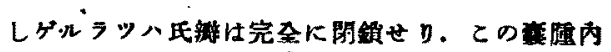

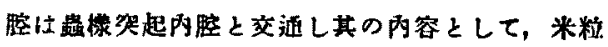
大球形の寒天楼物它を合有し，其の色は灰白色に

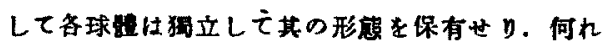

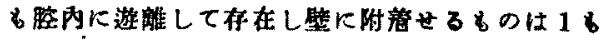
無く其の数䄪 200 稀简を算せり. 本例は 1914 年 v. Hangemann に化り始めて Myxoglobulose der Appendix と命名されしいのなり.1931 年に

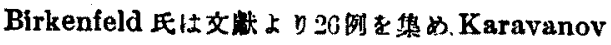

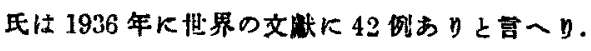

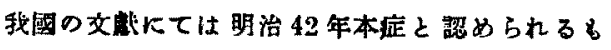
のを佐薜氏が始めて器表して以来現在迄に余の症 
例を合して僅かに 13 例のみなり.斯くの如く本

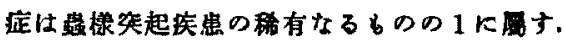

\section{4. 溷盲部疾患の应侧}

\section{神戸日赤 渡 遭 傅 二}

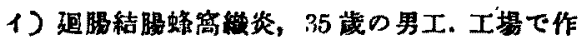

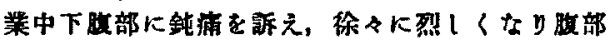

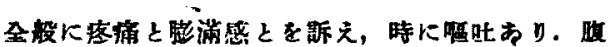

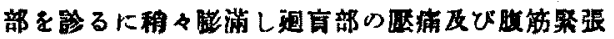

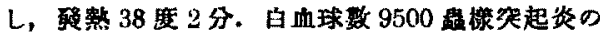

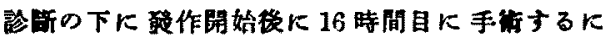

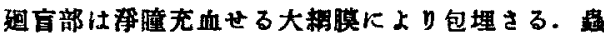

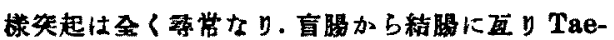
nia libera の外側火䄪 $8 \mathrm{~cm}$ の長さに於て娟管は

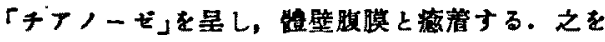

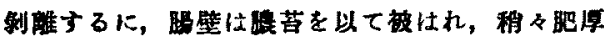

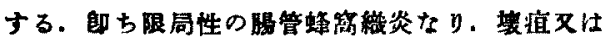

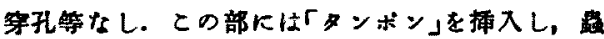

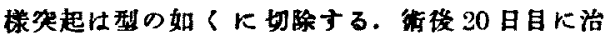

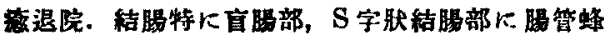

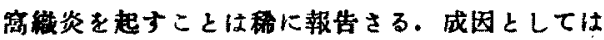

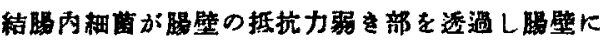
鱼性炎街を起すに因る，從而便皏，烡物に上る粘

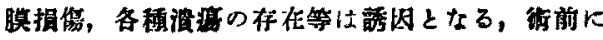

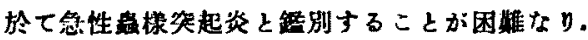

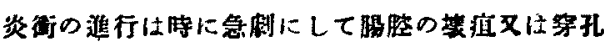

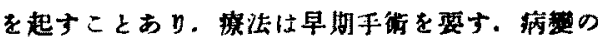

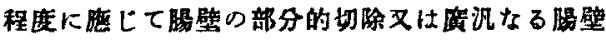

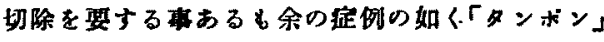
挿入にして治虚せしむることもおり。

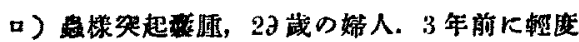

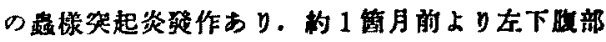

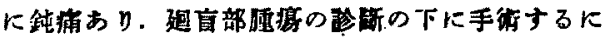

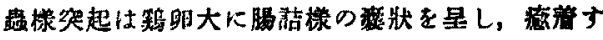

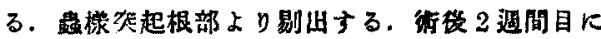

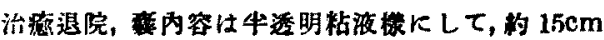

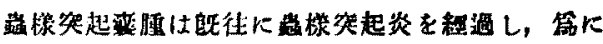

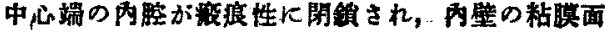

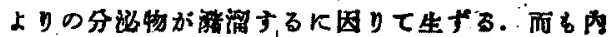

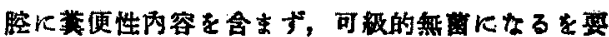
す.療法は手行の他なし。

35. 直湯癌の紿計的数察 石山外科 青山 鬿

缺 席

36. $1 ， \mathrm{~S}$ 宇結腸拎轉症の 1 例

口，直腸癌根洽手街に對する䋣見

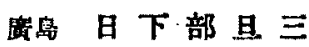

缺 席

（番外）䛲䐬皮下破裂治驗例

高知杉佐助

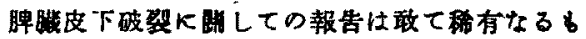

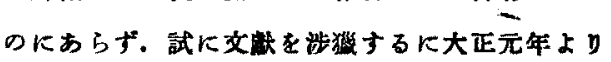
昭和 13 年来に至る最近的 30 年間に本邦に於ける

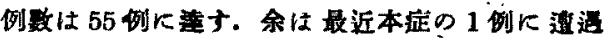
し幸にして治庵せしめ得たるを以て道加報告せん

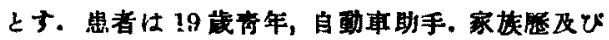

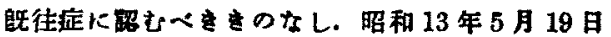

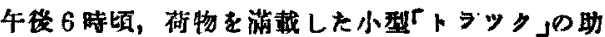

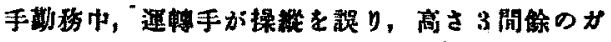

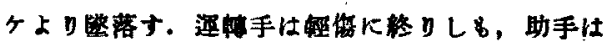

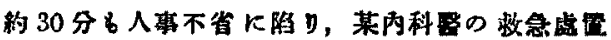

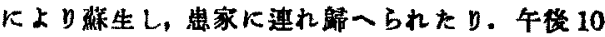

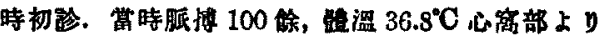

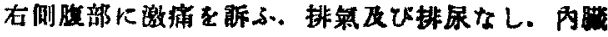

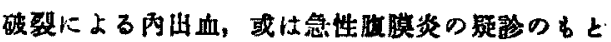

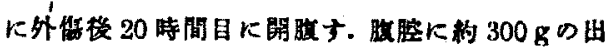

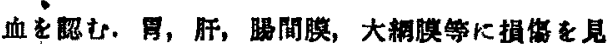

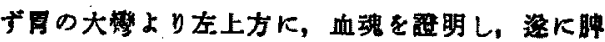

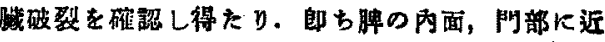

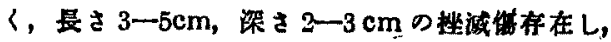

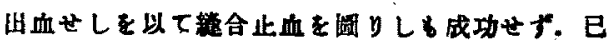

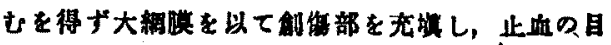


的を造し得たり。幸に费者江潼良好で目下 15 日，近退院の定士り。

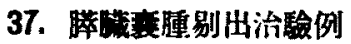
津田外科 矢 部 正 崔

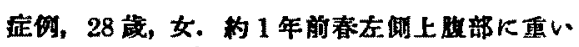

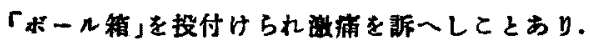

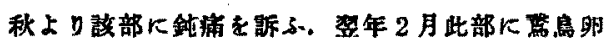

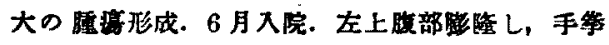

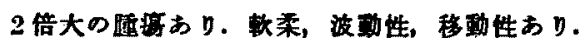

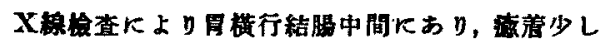

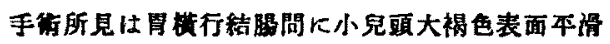

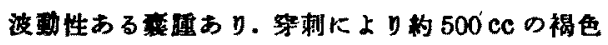

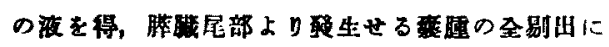

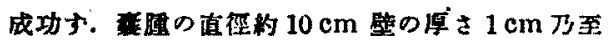

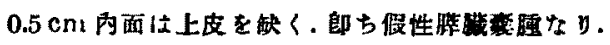

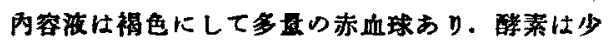

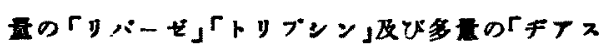
タービ」を含有子。

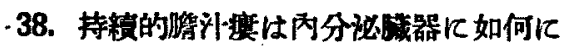
影幚を及性すゃ

$$
\text { 石山外科 北 山三 郎 }
$$

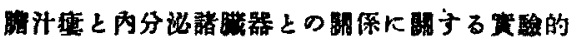
西究汢甲狀腺に於ては多少の報告あるる其の他の

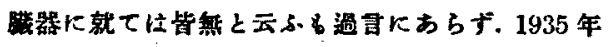

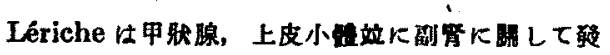

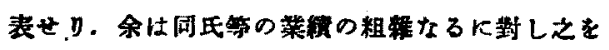

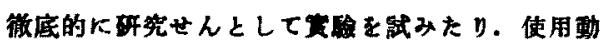

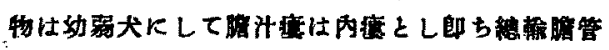

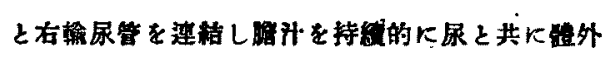

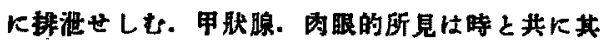
の大さ及び重量を加す。其の速度は中等度士

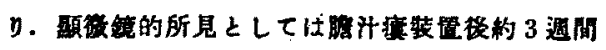

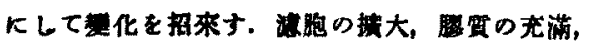

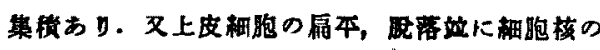

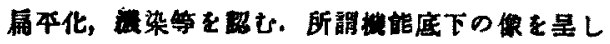

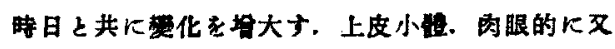

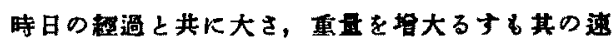

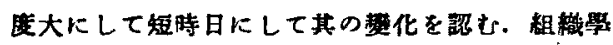
的所完に於て恃肥大透明緗胞组现し激次其の肥 大，透明性を管加の候向あり。核方亦其の大さを

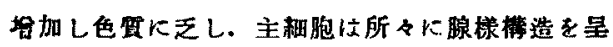

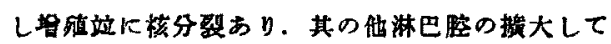
中к水栐透明物留の充满せるととあり，以上上り して機能元進の像なり.刷堅. 肉眼的所見として 時間的に及其の大さ，重量を管加するる其の速度

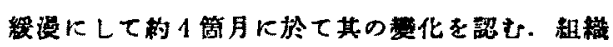

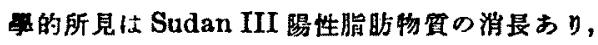

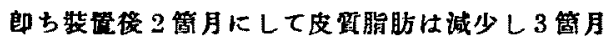

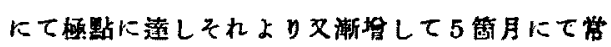

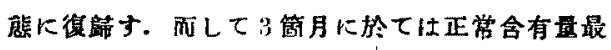

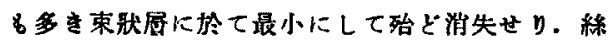

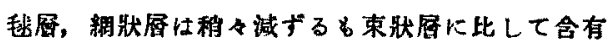

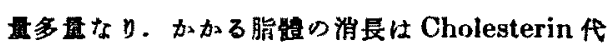

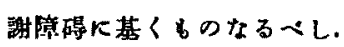

\section{9. 特墢性總输啲管震腫}

\section{新原病院 小吙 敏 彰}

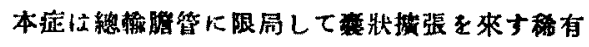

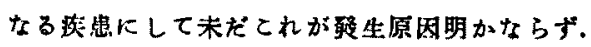

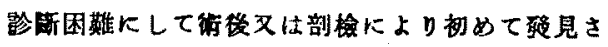
るるもの多し、最近余等は 35 歲の女子にして右

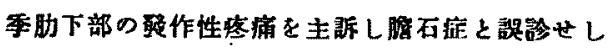
本庭の 1 例火造遏せしを以て報告せんとす。

追加煀山川崎融宣

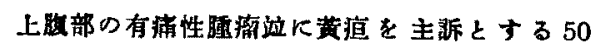

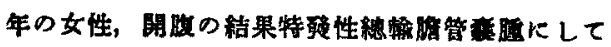

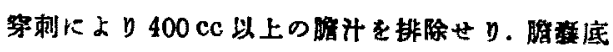

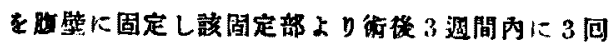

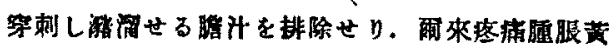
㾞などを略一ず。 


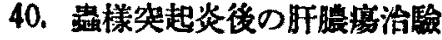

因豩小野 雄 管

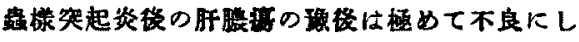

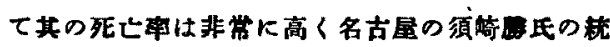

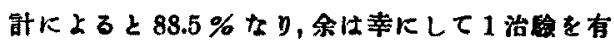
士. 患者星加某 28 歳の女，粎 60 日前分始 昭和 13

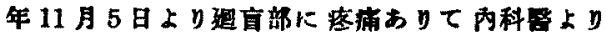

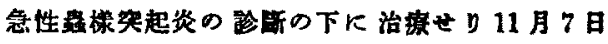

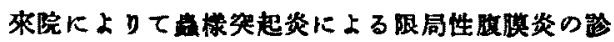

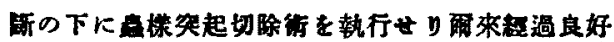

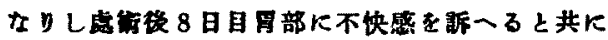

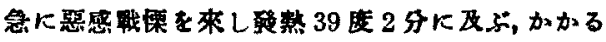

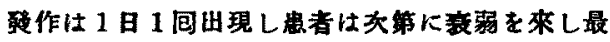

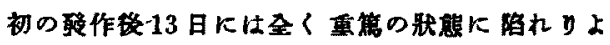

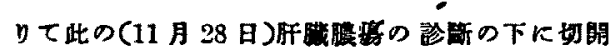

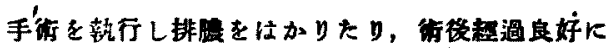
して 12 月.28 日全治退院せり.

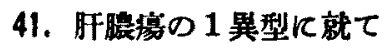

$$
\text { 高松三宅德三郎 }
$$

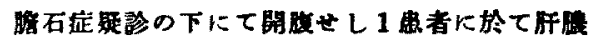

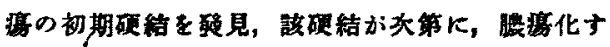

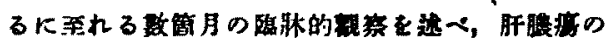

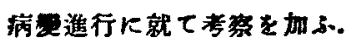

追加石山数投

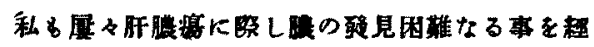

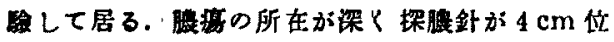

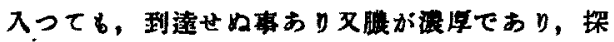

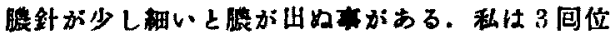

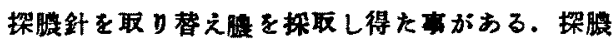

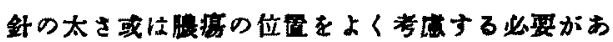
3.

42、心䐟外科に於ける 2,3 知見補䢔

间山楖原亭

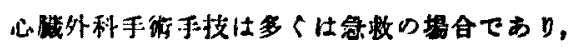

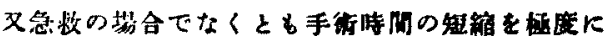

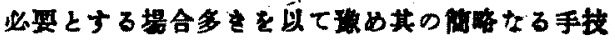

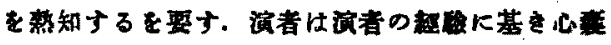

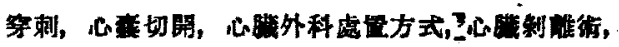

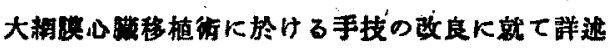
t.

43. 內外境域問題に就て

$$
\text { 石山外科石山福二郎 }
$$

内外境域問题を，おる1つの患を中心にして

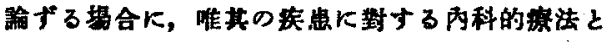

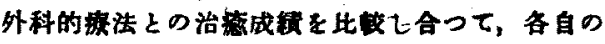

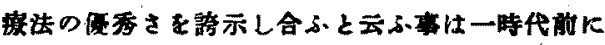

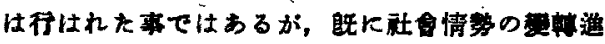
步した現時に於ては，極めて因隻的な通念上云人

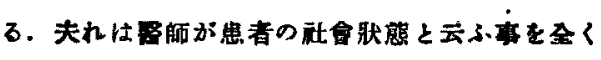
确虑ぜ゚，唯理諭のみから出して自己の信ナ゙

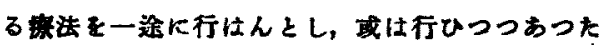

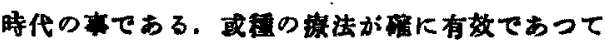

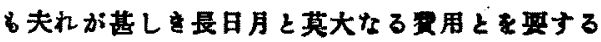

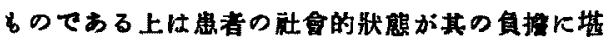
天ざる限り，決して理想的に治撩の完了を期し得

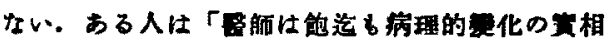

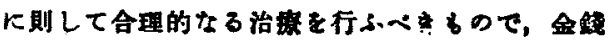

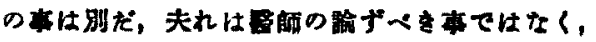
社合矿然家に委すべであると云ふ。无い千萬の

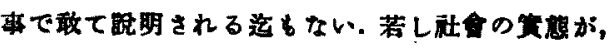

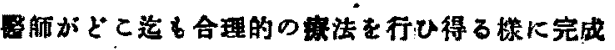

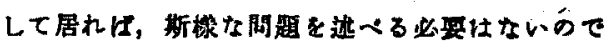

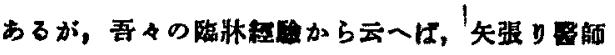

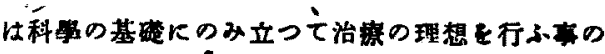

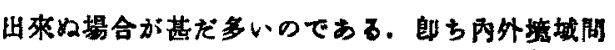

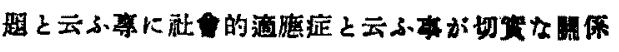

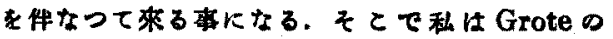
主镸斿 3 Diagnose des Zustandes $と$ Diagnose der Bedeutung $上$ 呤昧し，更K Siebeck $の$ 矢

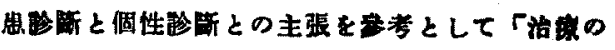

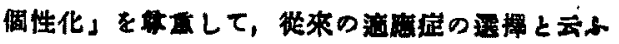




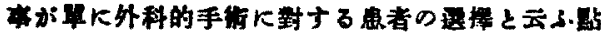

のみK止らず，內科的にある治療を行ふ場合一

珠にそれが所筋“境城突患”である場合に一一内

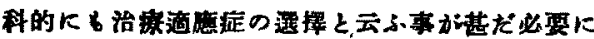

なるるのであると云ふ所以を例證をひいてのへて

見たいのでる。

\section{1 簡易租維診断法}

津田外科 津 田誠 次

Broders 氏
Clinic, XXIII, 1931 K Wilson 氏心幾法吉距戴 してるる。其の方法は常の如く新鮮租禨を涷結切 片となし，Terry 氏中性 Polychromes Methylenblau で染色し，水洗したる㷋直ちに水火封鎮 したままで鏡检するので，操作が简單で 1 分以內

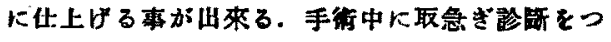
け手街の方針を決定せ机ばなら旺には至梗便利

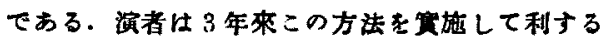
ところが少くない，色素は伯林の Leit”の店で搏 蜼してるる。 